\title{
Analysis of carbon stock and radial growth of trees through tree ring analysis in pine forest of linga guthi in Bhaktapur, Nepal
}

\author{
Saphalta Chhukan ${ }^{1}$, Siddi Bir Karmacharya ${ }^{1}$ and Sanu Raja Maharjan ${ }^{1} \bowtie$ \\ 1Department of Environmental Science, Khwopa College, Bhaktapur, Nepal \\ botanysanu@hotmail.com
}

\begin{abstract}
Forests are the integral to the global carbon cycle. These ecosystems sequester carbon in the plant biomass and in the soil. The study was carried out in Linga Guthi Community Forest of Bhaktapur to estimate carbon Stock and radial growth of Pinus roxburghii through tree ring analysis. A total of 32 circular plots of $250 \mathrm{~m}^{2}$ area were laid down randomly. Subplots were made for study of saplings, Litter, herbs and soil. For tree ring analysis, tree core samples were collected from different blocks of forest. Ring widths were measured using TSAP-Win Software attached to a LINTAB measuring system. For tree ring analysis, COFECHA and ARSTAN program were used. The average carbon stock of Linga Guthi Community Forest was $272.22 \pm 17.36 \mathrm{t} / \mathrm{ha}$. Similarly, it has storage of $206.87 \pm 4.47 \mathrm{t} / \mathrm{ha}$ AGTC, $41.37 \pm 2.19 \mathrm{t} / \mathrm{ha}$ BGTC, $23.814 \pm 1.00 \mathrm{t} / \mathrm{ha}$ SOC. The carbon sequestration rate of the forest was $2.22 \mathrm{Ct} / \mathrm{ha} /$ year. The average radial growth of pine trees in the forest was found to be $2.06 \pm 0.13 \mathrm{~mm} /$ year. The maximum radial growth was $4.47 \mathrm{~mm} / \mathrm{yr}$. The oldest tree recorded in this forest was 158 years with $58 \mathrm{~cm}$ diameter. However the average age of the forest was 98 years. The ring width chronology of 158 years was prepared for pine tree extending from 1854 to 2013 A.D.
\end{abstract}

Keywords: carbon sequestration, dendrochronology, growth rate, ring width

\section{INTRODUCTION}

Globally, forests act as a natural storage for carbon, contributing approximately $80 \%$ of terrestrial above-ground, and $40 \%$ of terrestrial below-ground biomass carbon storage (Krischbaum, 1996). They play a critical role in reducing ambient $\mathrm{CO}_{2}$ levels, by sequestering atmospheric carbon into the growth of woody biomass through the process of photosynthesis and also by increasing the soil organic carbon (SOC) content (Brown \& Pearce, 1994). Carbon sequestration from atmosphere can be advantageous from both environmental and socioeconomic perspectives.

Forest ecosystems play a crucial role in regional and global terrestrial carbon $(C)$ cycles because they store large quantities of $C$ in vegetation, detritus, and soil, and exchange large amounts of C with the atmosphere through photosynthesis and respiration (Dixon et al., 1994. The major carbon pools to be measured in forest carbon estimation are plant biomass (Above and below ground), above ground sapling biomass (AGSB), soil organic carbon (SOC), and litter, herbs, and grass (LHG) (IPCC, 2006). As the tree biomass experience growth, the carbon held by the plant also increases the carbon stock (Jana et al., 2009). The rate of carbon storage increases 
in young stands, but then declines as the stand ages (Jana et al., 2009). Tree ring records can go back hundreds to thousands of years, depending on when the tree lived and how old it was and also helps to know past climate condition (Fritts, 1976). The tree ring produced in any year can be influenced directly by the climate of the year of formation, and indirectly by the climate of prior years. Dendrochronology gives baseline information about the forest structure, total Carbon Stock, sequestration rate and it's Radial Growth in forest (Fritts, 1976).

To mitigate climate change and control of global warming, community-based forest management has an significant role to play in sequestering carbon, reversing processes of deforestation, and promoting rural development (Klooster \& Masera, 2000). The role of community forest is well known in sequestration of carbon, and more information is needed about functioning as source and sink of GHGs.

In Nepal, most studies has been conducted in forest for their tangible economic benefits where as very few studies have been done on intangible benefits like carbon sequestration (Shrestha \& Singh, 2008). Forests exchange large amounts of $\mathrm{CO}_{2}$ with the atmosphere and are able to sequester large amounts of $\mathrm{CO}_{2}$ into biomass (Moroni, 2012). The role of community forest is well known in sequestration of carbon, and more information is needed about functioning as source and sink of GHGs. Through the tree ring analysis, the annual growth of the community forest and age of the tree can be estimated. Tree rings have been widely used in dating the

past environmental events such as climate (Cook \& Kairiukstis, 1990; Fritts, 1976), fire, forest structure and dynamics, landslide, earthquake also.

\section{MATERIALS AND METHODS}

The study was carried out in Linga Guthi Community Forest (LGCF) of Bhaktapur, at Chittapol VDC. The forest constitutes a natural chir pine (Pinus roxburghii) forest along with few patches of other species.

Stratified random sampling was done in the forest area for estimation of forest carbon. 32 Circular plots of $250 \mathrm{~m}^{2}$ area were sampled in the forest. The circular plot of $8,92 \mathrm{~m}$ was established to measured Above ground tree biomass (AGTB). For estimating the tree biomass, equation developed by (Chave et al., 2005) for moist climate was used according to the carbon inventory guidelines given by Subedi et al. (2005).

\section{Above Ground Tree Biomass (AGTB) $=0.0509 \times \mathrm{DD}^{2} \mathrm{H}$}

Where, $A G T B=$ Above ground tree biomass $(\mathrm{kg}), \rho=$ wood specific gravity $\left(\mathrm{gm} / \mathrm{cm}^{3}\right), D=$ tree diameter $(\mathrm{cm})$ and $\mathrm{H}=$ tree height $(\mathrm{m})$

Sub plots were established within each plot for estimating carbon in saplings, litter/herbs and soil. Sub plots with a $5.64 \mathrm{~m}$ radius were established for saplings; and subplots with $0.56 \mathrm{~m}$ radius was established for sampling leaf litter, herbs, grass, and soil.

The following regression model developed by Tamrakar (2000) was used to calculate sapling biomass.

$\ln (A G S B)=a+b \ln (D)$

where AGSB = Above ground sapling biomass 
For calculating below ground biomass of trees, root to shoot ratio value of 1:5 was used ie $20 \%$ of above ground tree biomass as recommended by (Mac Dicken, 1997). Similarly the biomass stock was converted into carbon stock after multiplication with the IPCC (2006) default carbon fraction of 0.47 .

For determining soil organic carbon Walkely and Black Method (1934) was used. Soil samples were collected from each sub plots of $0.56 \mathrm{~m}$ up to $30 \mathrm{~cm}$ depth.

Standard increment borer (Swedish Haglöf 16", 3-Thread, 0.200" (5.15 mm) diameter was used to extract the core samples from selected trees from each quadrat samples. Two cores were collected from 36 sample trees. Core samples were labeled, mounted and core surfaces were sanded manually through grades of progressively finer grit sand paper such as $120,320,400,600,800$ and 100 sand papers until the ring boundaries are visible under binocular microscope. The LINTAB measurement system with a LINTAB moving stage and stereomicroscope, attached to PC having TSAP-Win program was used to measure the ringwidths of each series at dendrochronological laboratory of Department of Forest research and survey (DFRS) in Babarmahal, Kathmandu. The age of trees was determined using dendrochronological techniques ( 1 annual ring=1 year). For determining the radial growth and preparing the chronology, COFECHA and ARSTAN Program was used.

\section{RESULTS AND DISCUSSION}

The average carbon stock of the LGCF was $272.229 \pm 17.316$ t/ha including soil organic carbon, tree biomass carbon, litter/herbs/grass (LHG) and saplings. The distribution of carbon in different pools is shown in fig 1. The total carbon stock of the studied forest with area 19.48 ha area was found to be 5303.02t. Comparatively less carbon was present in sapling and LHG in the forest. The average carbon stock estimated for chirpine in Bhaiyadevi CF, Salyan was $72.86 \mathrm{t} / \mathrm{ha}$ with an annual carbon sequestration rate of $2.21 \mathrm{t} / \mathrm{ha} / \mathrm{yr}$. Baral et al. (2009) have estimated above-ground carbon stock of 34.30- 97.86 dry wt. ton ha-1 and rate of carbon sequestration (1.30-3.21 t/ha/yr), in different forest types. Hence the present findings show that the forest is well stocked with higher value of carbon stock and sequestration rate.

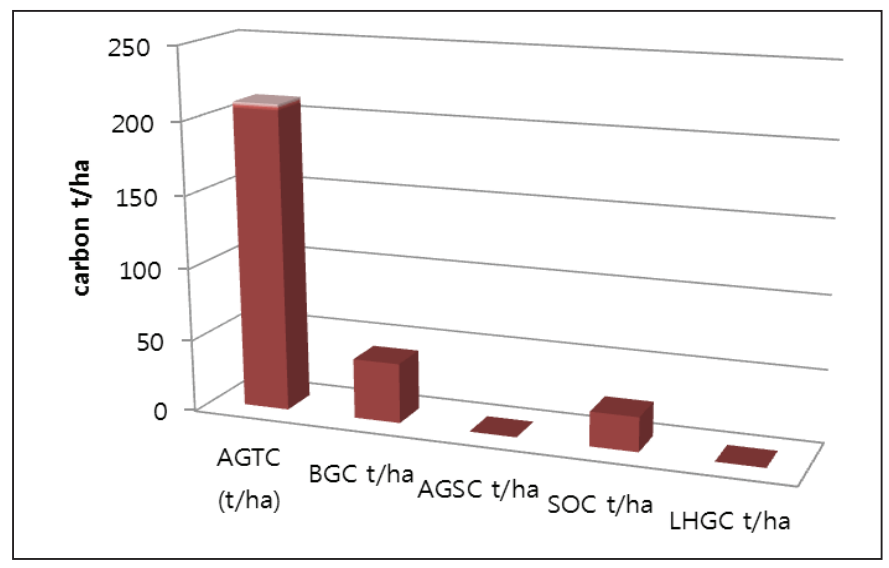

FIG. 1. Total carbon stock of forest. 


\section{Radial growth of pine trees}

Similar sized tree of the same species from same sites may grow with different rate. The overall growth of pine tree in LGCF was found to be $2.0619 \pm 0.139 \mathrm{~mm} /$ year whereas maximum radial growth was $4.472 \mathrm{~mm} / \mathrm{yr}$.

After the visual cross dating under the LINTAB microscope, ring of each core were measured and counted the ring number that gave age of tree. The tree rings numbers were plotted against diameter to see the relationship between diameter and age. There was significant positive relation between diameter and age in linear growth. The relation between radial growth, age and $\mathrm{DBH}$ are also shown in fig. 3 and 4.This chronology shows the negative correlation between radial growth rate and age and relation between growth rate and $\mathrm{DBH}$. Ring width often decrease with increasing tree age. There was negative correlation between radial growth rate and age and relation between growth rate and $\mathrm{DBH}$. Ring-widths often decrease with increasing tree age. The cumulative growth rate was also in negative correlation as shown in fig. 5. This biological growth trend is usually independent of other factors influencing tree growth (e.g. climate) and it is often helpful to remove it by a curvefitting procedure prior to further analysis (Fritts, 1976).

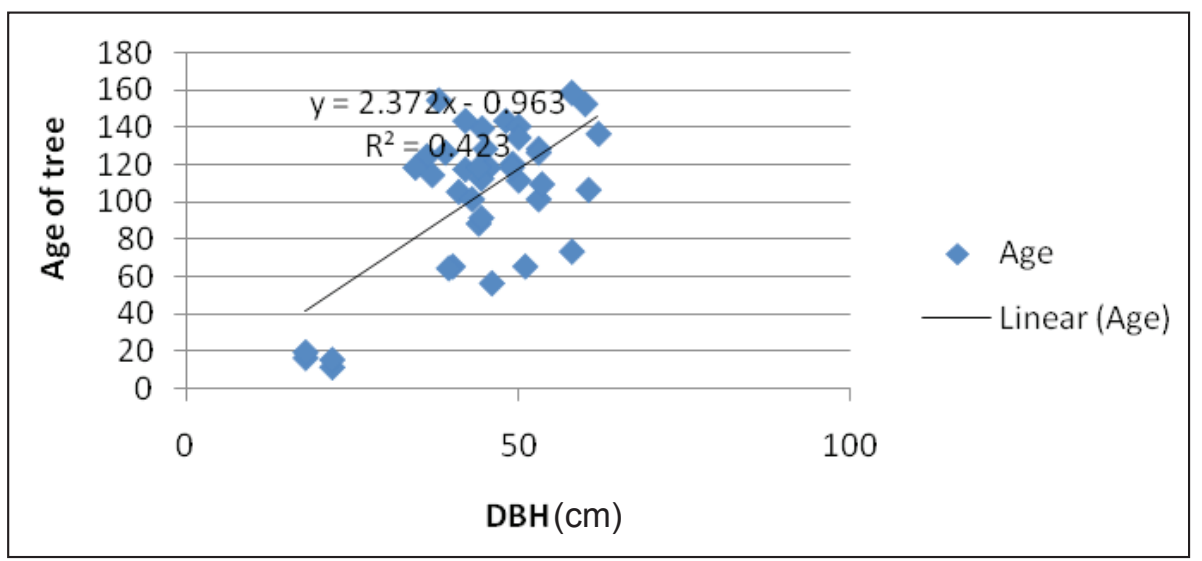

FIG. 2. Diameter-age relationship of Pinus roxburghii in Linga Guthi CF.

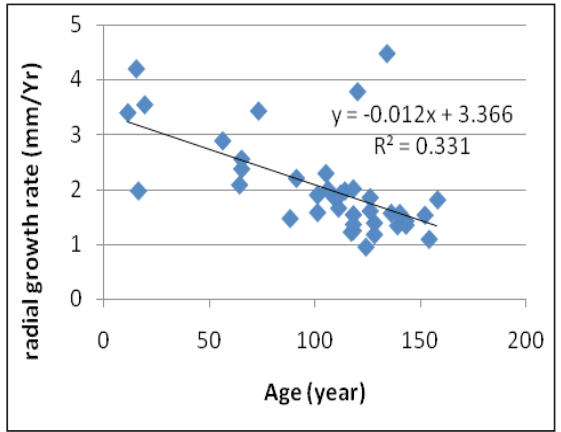

FIG. 3 Radial growth-age relationship.

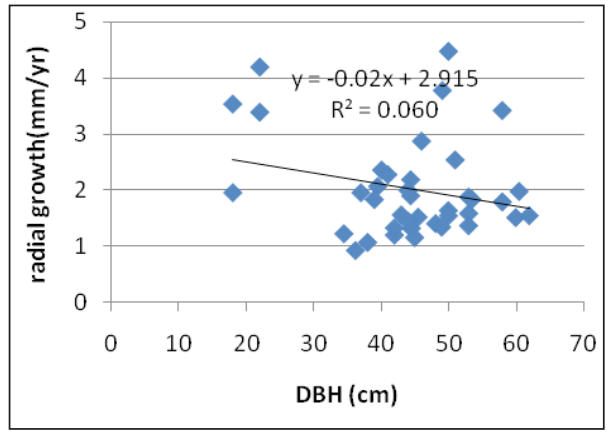

FIG. 4. Radial growth - DBH relationship. 


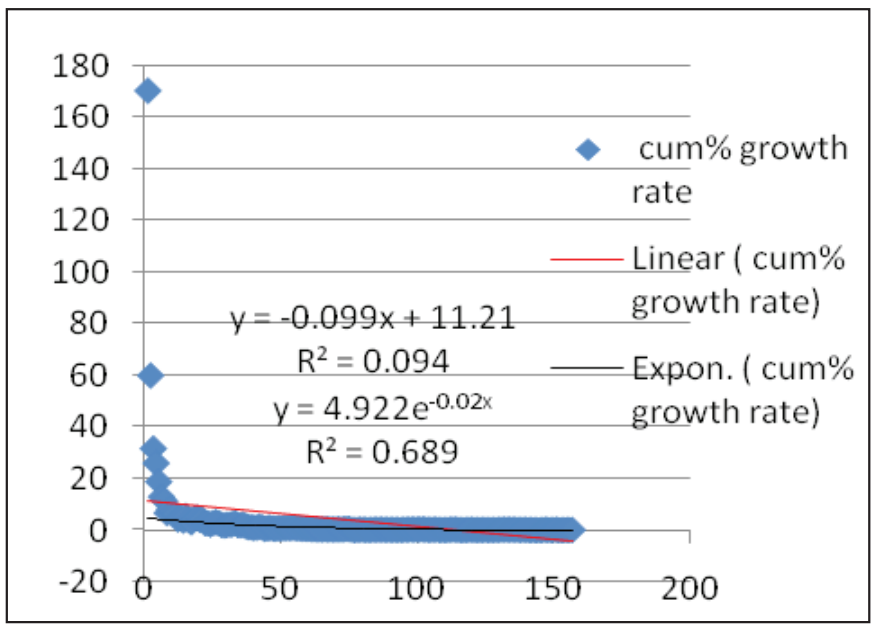

FIG. 5. Cumulative growth rate (\%).

\section{Age of pine forest}

The oldest tree recorded in this forest was 158 years with $58 \mathrm{~cm}$ diameter. However the average age of the forest was 98 years. The tree age corresponding calendar started from 1854 to 2013 A.D. (table 1).

TABLE 1. Descriptive statistics of the radial growth and age of Pinus roxburghii in Linga Guthi Community Forestry, Bhaktapur.

\begin{tabular}{|l|l|l|l|l|l|}
\hline $\begin{array}{l}\text { Mean } \\
\text { DBH(cm) }\end{array}$ & $\begin{array}{l}\text { Max DBH } \\
(\mathbf{c m})\end{array}$ & $\begin{array}{l}\text { Max } \\
\text { age } \\
\text { (year) }\end{array}$ & $\begin{array}{l}\text { Min } \\
\text { age } \\
\text { (year) }\end{array}$ & $\begin{array}{l}\text { Tree age corresponding } \\
\text { calendar (year) }\end{array}$ & $\begin{array}{l}\text { Radial growth } \\
\text { (mm/yr) }\end{array}$ \\
\hline 39.74 & 62 & 158 & 11 & $1854-2013$ & $2.0619 \pm 0.139$ \\
\hline
\end{tabular}

\section{Annual rate of carbon sequestration in aboveground tree biomass}

It was found that $2.22 \mathrm{t}$ of carbon/ha was sequestered in aboveground tree biomass each year. In young trees, there is increased annual net productivity which directly indicates increase in forest biomass and hence higher carbon sequestration potential (Adhikari, 2011). Jina et al. (2008) studied same species at Kumaun, Central Himalaya of India and found carbon sequestration rate of $5.06-6.66 \mathrm{t} / \mathrm{ha} / \mathrm{yr}$ in non-degraded forest and $1.07-1.27 \mathrm{t} / \mathrm{ha} /$ $\mathrm{yr}$ in degraded sites. The lower carbon sequestration rate in the forest may be due to the degradation by logging for religious purposes or soil nutrients and other climatic factors.

\section{Ring width chronology}

A 158 year long ring-width chronology of Pinus roxburghii was developed extending from 1854 to 2013 AD. The chronological statistics for the entire period as well as for the common period are given in table 2. The ring width standard chronologies were prepared and shown in fig. 6, 7 and 8. 
TABLE 2. Chronological statistics of Pinus roxburghii.

\begin{tabular}{|l|l|l|}
\hline Statistics & Standard chronology & Residual chronology \\
\hline Chronology span & $1854-2013 \mathrm{AD}$ & $1854-2013 \mathrm{AD}$ \\
\hline No. of radii & 75 & 75 \\
\hline Mean sensitivity & 0.089 & 0.098 \\
\hline Std. deviation & 0.129 & 0.101 \\
\hline $1^{\text {st }}$ order correlation & 0.502 & -0.003 \\
\hline Common period & $1939-2013 \mathrm{AD}$ & $1939-2013 \mathrm{AD}$ \\
\hline Correlation between radii $\left(\mathrm{r}_{\mathrm{a}}\right)$ & 0.034 & 0.024 \\
\hline Correlation between tree $\left(\mathrm{r}_{\mathrm{b}}\right)$ & 0.031 & 0.023 \\
\hline Correlation within tree $\left(\mathrm{r}_{\mathrm{w}}\right)$ & 0.223 & 0.122 \\
\hline SNR & 1.923 & 1.345 \\
\hline EPS & 0.658 & 0.573 \\
\hline
\end{tabular}

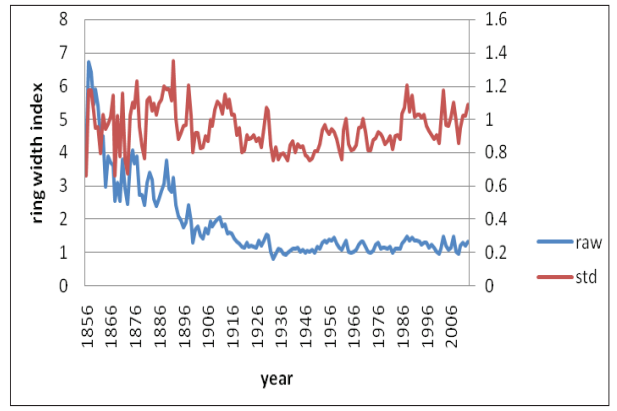

FIG. 6. Standard and residual chronology of ring width index and age.

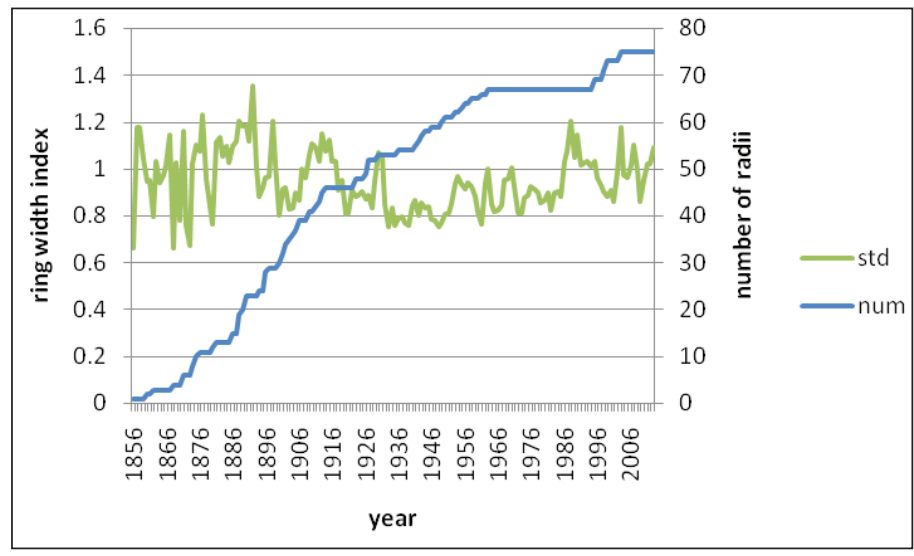

FIG. 8. Standard chronology and sample depth of Pinus roxburghii. 
For common period of (AD 1939-2013) various statistics like correlation, EPS, SNR and variance explained were computed. The mean sensitivity of standard and residual chronology was found to be 0.089 and 0.098 respectively. The first order correlation was 0.502 . Here First order autocorrelation decreased to -0.003 in residual chronology because autocorrelation is removed from standard chronology to get residual chronology. The mean correlation within tree, between trees and among all radii was estimated. The mean correlation within tree was greater than 0.122 than correlation between tree and among all radii. Lower value of correlation coefficient has been recorded for both the chronologies however the coefficient was less for between trees and among all radii. The EPS for standard and residual chronology was 0.658 and 0.573 respectively. Both chronologies did not exceed the EPS limit of 0.85 indicating that the site chronology does not represent the well population chronology.

Above ground tree biomass and carbon in the forest is higher compared to other studies. Carbon sequestration rate of $2.22 \mathrm{t} \mathrm{C/ha}$ was found in aboveground tree biomass each year. Linga Guthi CF is one of the old forests in the valley as 158 years old pine with $58 \mathrm{~cm} \mathrm{DBH}$ was recorded. The tree age corresponding calendar was started from 1854 to 2013 A.D. The average radial growth of pine tree was found to be $2.0619 \pm 0.139 \mathrm{~mm} / \mathrm{year}$. The age and DBH relationship show positive correlation. The radial growth rate of tree show negative correlation with age and $\mathrm{DBH}$ of trees. This biological growth trend is usually independent of other factors influencing tree growth (e.g. climate).

Thus, Linga Guthi CF has higher potential of carbon sequestration and pine trees stored large amount of carbon. The forest is being degraded by logging of mature trees for traditional and religious festivals of Kathmandu and Bhaktapur. As old pine trees in this forest preserve records of past environmental histories, other alternatives seem necessary to control logging and to conserve the forest.

\section{ACKNOWLEDGEMENTS}

We are thankful to Mr. Shekhar Khadka, Secretary of Linga Guthi user group for their generous help. Sincere thanks to Mr. Deepak Khadka, Director General, Department of Forest Research and Survey for providing the equipments and Dendro lab facilities in DFRS. We are thankful to Mr. Narayan P. Gaire, PhD, for helping in data analysis.

\section{REFERENCES}

ADHIKARI, M D (2011) Evaluating annual carbon balance of aboveground woody biomass in of mid-hills, Nepal: a case study of Bhaiyadevi in Salyan district. Master Thesis, Institute of Botany and Landscape Ecology, Ernst Mortiz Arndt University Greifswald, Greifswald, Germany.

BARAL, S K; MALLA, R; RANABHAT, S (2009) Above-ground carbon stock assessment in different forest types of Nepal. Banko Jankari 19(2): 10-14.

BROWN, K; PEARCE, D (1994) The economic value of non-market benefits of tropical forests: carbon storage. In Weiss, J (ed) The economics of project appraisal and the environment: New horizon in environment economics. E. Elgar, Aldershot; pp 102-119.

CHAVE, J; ANDALO, C; BROWN, S; CAIRNS, M A; CHAMBERS, J Q; EAMUS, D (2005) Tree allometry and impoved estimation of Carbon Stocks. Oecologia, 145: 87-99. 
COOK, E R; KAIRIUKSTIS, L A (1990) Methods of dendrochronology: applications in the environmental sciences. Kluwer Academic Publishers, The Netherlands.

DIXON, R K; BROWN, S; HOUGHT, R A; SOLOMON, A M; TREXLER, M C; WISNIEWSKI, J (1993) Carbon pool and flux of global forest ecosystem. Science 263: 185-190.

FRITTS, H C (1976) Tree rings and climate. Academic Press, London, UK.

IPCC (2006) Good practice guidelines for national greenhouse gas inventories. Intergovernmental Panel on Climate Change, Switzerland.

JANA, B K; BISWAS, S; MAJUMDER, M; ROY, P K; MAZUMDAR, A (2009) Comparative assessment of carbon sequestration rate and biomass carbon potential of young Shorea robusta and Albizzia lebbek. International Journal of Hydro-Climatic Engineering 1: 1-15.

JINA, B S; SAH, P; BHATT, M D; RAWAT, Y S (2008) Estimating carbon sequestration rates and total carbon stock pile in degraded and non-degraded sites of oak and pine forest of Kumaon central Himalaya. Ecoprint 15: 75-81.

KOOSTER, D; MASERA, O (2000) Community forest management in Mexico: carbon mitigation and biodiversity conservation through rural development. Global Environmental Change 10(4): 259-272.

KRISCHBAUM, M U F (1996) The carbon sequestration potential of tree plantations in Australia. Pp.7789. In Eldridge, K G; Crowe, M P; Old, K M (eds) Environmental management: the role of Eucalypts and other fast growing species. CSIRO Forestry and Forest Products. Canberra, Australia.

MACDICKEN, K G (1997) A guide to monitoring carbon storage in forestry and agro forestry projects. Winrock International, Arlington, USA.

MORONI, M T (2012) Aspects of forest carbon management in Australia-a discussion paper. Forest Ecology and Management 275: 111-116.

SHRESTHA, B M; SINGH, B R (2007) Soil and vegetation carbon pools in a mountainous Watershed of Nepal. Department of Plant and Environmental Sciences (IPM), Norwegian University of Life Sciences (UMB), Norway.

SUBEDI, B P; PANDEY, S S; PANDEY, A; RANA, E B; BHATTARAI, S; BANSKOTA, T R; CHARMAKAR, S; TAMRAKAR, R (2010) Guidelines for measuring carbon stocks in community-managed forests. ANSAB, ICIMOD, FECOFUN, NORAD.

TAMRAKAR, P R (2000) Biomass and volume tables with species description for community forest management. MoFSC, NARMSAP-TISC, Kathmandu, Nepal.

WALKELY, A E; BLACK, J A (1934) An examination of the Degtjareff method for determining soil organic matter, and proposed modification of the chronic acid titration method. Soil Science 37: 29-38. 